\title{
СОВРЕМЕННЫЕ ПОДХОДЫ К АНАЛИЗУ \\ ЭФФЕКТИВНОСТИ ФУНГИЦИДНЫХ ПРЕПАРАТОВ, С УЧЕТОМ СПОСОБНОСТИ МИКРОСКОПИЧЕСКИХ ГРИБОВ СУЩЕСТВОВАТЬ В УСЛОВИЯХ ОБРАЗОВАНИЯ БИОПЛЕНОК
}

\section{С.А. Лисовская ${ }^{1,2,3}$, Р.И. Валиева ${ }^{1,2}$, Л.Е. Никитина ${ }^{2,3}$, А.Р. Каюмов}

${ }^{1}$ ФБУН Казанский научно-исследовательский институт эпидемиологии и микробиологии

Роспотребнадзора, 420015, Россия, г. Казань, ул. Б. Красная, д. 67.

2ФГБОУ ВО «Казанский государственный медицинский университет»

Министерства здравоохранения РФ, 420012, Россия, г. Казань, ул. Бутлерова, 49.

${ }^{3}$ Казанский (Приволжский) федеральный университет, 420008, г. Казань, ул. Кремлевская, 18.

DOI: 10.19163/MedChemRussia2021-2021-100

E-mail:S_lisovskaya@mail.ru

На сегодняшний день доклиническое исследование противогрибковой активности лекарственных средств in vitro проводят двумя вариантами: методом серийных разведений и диско-диффузионный. Каждый из методов обеспечивает быстрый ответ по чувствительности штаммов, при проведении исследования. Вместе с тем, используемые в рекомендациях суточные культуры клеток в данных методах дают нам представление о чувствительности клеток, находящихся только в планктонном состоянии. Тогда как, в настоящее время известно, что более $65 \%$ всех инфекционных заболеваний обусловлены микроорганизмами, существующими в форме биоплёнок. Способность грибов формировать биоплёночные структуры повышает устойчивость клеток к антимикотикам в десятки, а то и в сотни раз. Соответственно, необходим поиск новых перспективных химических веществ, с учетом современных принципов лечения микозов, которое должно быть, направлено и на фенотипическое разнообразие вида (биопленкообразование).

Приведённые данные послужили основанием для проведения исследования противогрибковой активности веществ (миртенол и флуконазол) в отношении грибов Candida albicans в планктонной форме и в составе биопленок. В результате определения чувствительности планктонных клеток штаммов C.albicans к веществам, выявлено, что грибы были чувствительны ко всем видам тестируемых веществ. Минимально ингибирующая концентрация (МИК) для флуконазола составила 25 мкг/мл, для миртенола 25 мкг/мл. В отношении биоплёнок концентация препаратов ингибирующая рост биоплёнок составила для флуконазола 1600 мкг/мл, для миртенола 400 мкг/мл.

Таким образом, МИК, подавляющая рост биоплёнок более чем в 50 раз превышает МИК, подавляющую рост планктонных клеток, что необходимо учитывать при оценки эффективности химических веществ с противогрибковой активностью.

Работа выполнена при поддержке гранта Российского Научного Фонда

(№20-64-47014).

$$
-100-
$$

